\title{
Primary breast double-hit lymphoma management and outcomes: a real-world multicentre experience
}

Tingting Zhang ${ }^{1}$, Yuanfeng Zhang ${ }^{1,2}$, Hairong Fei ${ }^{3}$, Xue Shi ${ }^{3}$, Liang Wang ${ }^{4}$, Peijun Wang ${ }^{5}$, Jie Yu ${ }^{6}$, Yuyan Shen ${ }^{1 *}$ and Sizhou Feng ${ }^{1 *}$ (D)

\begin{abstract}
Background: Primary breast double-hit lymphoma (PB-DHL) is a rare, highly aggressive malignancy that poses challenges regarding accurate diagnosis and selecting optimal treatment regimens.

Methods: We retrospectively reviewed 48 cases of patients diagnosed with PB-DHL in six academic centres between June 2014 and June 2020 in China. Study-specific data were recorded, including treatment options, therapeutic evaluation, prognostic factors and relapse patterns, and the overall survival (OS) and progression-free survival (PFS) were evaluated.

Results: In total, 48 patients were enrolled, with 14 patients treated with DA-EPOCH-R/MA (rituximab, dose-adjusted etoposide, prednisone, vincristine, cyclophosphamide, doxorubicin, alternating with high-dose methotrexate and cytarabine), 18 patients treated with DA-EPOCH-R (rituximab, dose-adjusted etoposide, prednisone, vincristine, cyclophosphamide, doxorubicin), and 16 patients treated with R-HyperCVAD (rituximab, hyperfractionated cyclophosphamide, vincristine, doxorubicin, dexamethasone, alternating with cytarabine plus methotrexate). The overall 5-year OS and PFS rates were $41.7 \%$ (95\% confidence interval [Cl], 27.6-56.8\%) and 37.5\% (95\% Cl, 24.0-52.6\%), respectively. Of the three treatment regimens, the 5-year OS was higher in DA-EPOCH-R/MA group than in the DA-EPOCH-R or R-HyperCVAD subgroups ( $57.1 \%$ vs. $38.9 \%$ vs. $31.3 \%$; $P=0.016)$, as was the 5 -year PFS ( $50.0 \%$ vs. $38.9 \%$ vs. $25.0 \%$; $\mathrm{P}=0.035$ ). Autologous stem cell transplantation (ASCT) prolonged the OS and PFS compared with non-ASCT patients (5-year OS: 72.2\% vs. 23.3\%; P<0.001; 5-year PFS: 72.2\% vs. 16.7\%, P<0.001). Multivariate analysis identified tumour size, risk stratification, treatment with DA-EPOCH-R/MA, breast irradiation, and ASCT as significant prognostic factors.
\end{abstract}

Conclusions: DA-EPOCH-R/MA is a promising regimen for PB-DHL, and breast irradiation yields complementary benefits for prognosis. ASCT significantly decreased disease relapse, providing a potential curative PB-DHL intervention and justifying ASCT as first-line therapy for young patients. More effective treatment strategies for PB-DHL patients remain encouraging.

Keywords: Primary breast lymphoma, Double-hit lymphoma, High-grade B-cell lymphomas, Therapy, Relapse, Prognosis

\footnotetext{
*Correspondence: shenyuyan@ihcams.ac.cn; doctor_szhfeng@sina.com ${ }^{1}$ Haematopoietic Stem Cell Transplantation Centre, State Key Laboratory of Experimental Hematology, National Clinical Research centre for Blood Diseases, Institute of Hematology and Blood Diseases Hospital, Chinese Academy of Medical Sciences and Peking Union Medical College, No. 288 Nanjing Road, Tianjin 300020, China

Full list of author information is available at the end of the article
}

\section{Introduction}

Primary breast lymphoma (PBL) is a rare subtype of breast malignancy, accounting for $1 \%$ of non-Hodgkin lymphomas and less than $3 \%$ of extra-nodal lymphomas [1-3]. The definition of PBL was proposed by Wiseman original author(s) and the source, provide a link to the Creative Commons licence, and indicate if changes were made. The images or other third party material in this article are included in the article's Creative Commons licence, unless indicated otherwise in a credit line to the material. If material is not included in the article's Creative Commons licence and your intended use is not permitted by statutory regulation or exceeds the permitted use, you will need to obtain permission directly from the copyright holder. To view a copy of this licence, visit http://creativecommons.org/licenses/by/4.0/. The Creative Commons Public Domain Dedication waiver (http://creativeco mmons.org/publicdomain/zero/1.0/) applies to the data made available in this article, unless otherwise stated in a credit line to the data. 
and Liao [4] in 1972, in which breast tissue was infiltrated by lymphoma cells with or without regional lymph node involvement. More than $95 \%$ of all diagnosed breast lymphoid malignancies are expected to be B-cell nonHodgkin lymphomas, such as follicular lymphoma and diffuse large B-cell lymphoma (DLBCL) $[5,6]$. The typical presentation is a unilateral painless breast mass in middle-aged women [2, 7]. However, accumulating evidence indicates that the morbidity continues to increase for younger women with increasing incidence over the last four decades [8]. Consequently, more attention is required. Double-hit lymphoma is high-grade B-cell lymphoma (HGBL) with MYC and B-Cell Leukaemia/Lymphoma $(\mathrm{BCL}) 2$ or BCL6 gene translocations detected by fluorescence in situ hybridization (FISH) or standard cytogenetics according to the National Comprehensive Cancer Network guidelines [9], representing a rare subtype with typical resistance to conventional therapy [10].

There are no accepted guidelines for standardised primary breast double-hit lymphoma (PB-DHL) treatment strategies, although combined chemotherapy and radiotherapy are presently the first-line therapeutics $[3,11$, 12]. Most studies still recommend the routine use of prophylactic central nervous system (CNS) therapy. However, the optimal approach for CNS prophylaxis remains unclear, and the CNS recurrence rate varies widely among studies [12, 13]. In light of the scarcity of data on Chinese patients, the disease is poorly understood, and no large studies have reported on PB-DHL treatment, making an accurate diagnosis and disease management a challenge [12]. The multicentre North-China collaboration was initiated to analyse the clinicopathologic features, explore effective curative options, and facilitate the development of effective prophylactic CNS strategies.

\section{Patients and methods}

The clinical data of consecutive patients between June 2014 and June 2020 were derived from six hospital databases in China. All diagnostic materials were recategorised and met the 2016 World Health Organization's (WHO) classification of lymphoid neoplasms [14]. The patients' pathological sections were rechecked by two senior pathologists. The inclusion criteria were: breast was the definite primary site, patients with $\mathrm{HGBL}$ with MYC and BCL2 or BCL6 gene translocations, and patients diagnosed at 60 years old or younger. Patients were excluded if they had a primary site that was difficult to confirm, had breast involvement secondary to systemic disease, had a prior diagnosis of haematologic malignancy, were histologically confirmed as non-HGBL, or had incomplete or missing outcome data. Based on the PBL definition, patients with bilateral breast involvement at the first diagnosis were classified as stage IV in this study. The collected data included clinicopathological results, the Ann Arbor staging classification, treatment strategies, adverse effects, and survival. After PB-DHL was diagnosed, computed tomography or positron emission tomography scans were performed for staging purposes. The response was evaluated by the time of completion or the initial treatment interim based on the revised version of the International Working Group in 2007 [15]. Toxic effects and haematological and non-haematological toxicity profiles were evaluated and graded based on the WHO's Common Toxicity Criteria (http:// ctep.cancer.gov, version 3.0). All patients were followed up until 1 July 2020. Informed consent was obtained from the patients or guardians of the study participants. All procedures followed the ethical standards of the Institutional Research Committee, and this study was approved by an appropriate ethics committee. The process of screening and identifying eligible patients is presented in Fig. 1.

\section{Statistical analyses}

The primary endpoints were overall survival (OS) and progression-free survival (PFS). The secondary endpoints were toxic effects and overall response rate (ORR), including complete remission (CR) and partial remission (PR). The baseline characteristics across the disease subgroups were compared using the Fisher's exact test. Survival was evaluated by Kaplan-Meier survival analysis, and any differences in survival were estimated using the log-rank test. Prognostic factors $(\mathrm{P}<0.1)$ in univariate analysis were subjected to the Cox proportional-hazards model for multivariate survival analysis to determine the simultaneous impact of prognostic factors on survival. Interactions between prognostic factors were also assessed using the Cox proportional-hazards model. OS was determined from the date of diagnosis until the death date or last follow-up. PFS was calculated from the date of diagnosis to the date of the first progression, relapse, or death of any cause. All statistical analyses were performed using GraphPad Prism software version 8.0 (GraphPad Software Inc., San Diego, CA, USA) and $\mathrm{R}$ version 3.4.3 (R Foundation for Statistical Computing, Vienna, Austria). Statistical significance was set as a twotailed P-value $<0.05$.

\section{Results}

\section{Baseline characteristics}

Totally 48 patients were enrolled in this study. The baseline characteristics of the 48 enrolled patients are presented in Table 1 . The median age was 48 years (range, 24-61 years). A painless unilateral breast mass was present in 38 patients $(79.2 \%)$, and the left breast was involved more often than the right $(45.8 \%$ vs. 


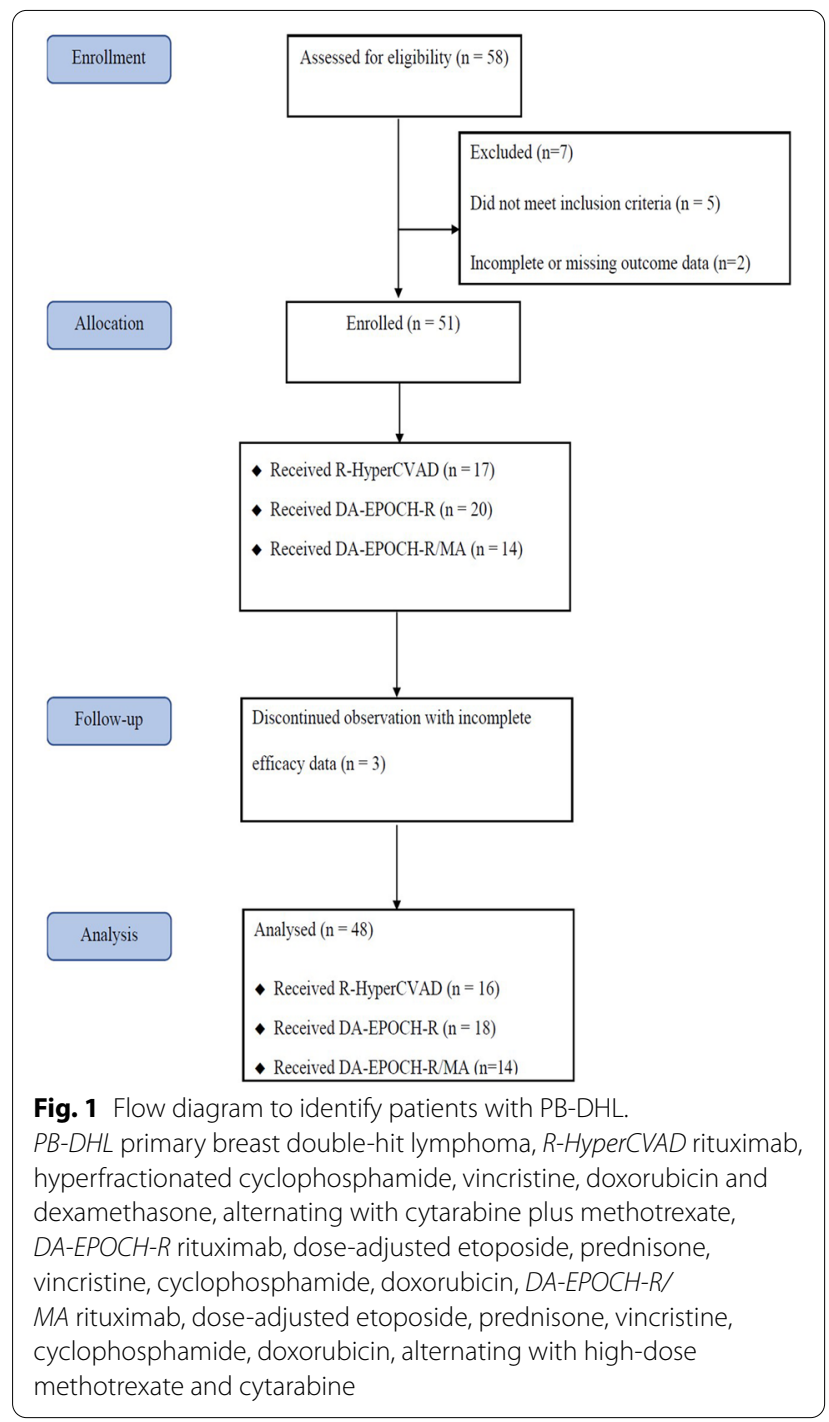

$33.3 \%$ ). The median tumour size was $2.6 \mathrm{~cm}$ (range, $0.9-11.5 \mathrm{~cm}$ ); 17 patients had a tumour $>5 \mathrm{~cm}$, and one had a tumour $>10 \mathrm{~cm}$. There were 13 patients classified as Ann Arbor stage IE, 21 classified as IIE, and 14 classified as IV. Risk stratification was investigated based on age-adjusted International Prognostic Index scores; 27 patients fell into the low- and low-intermediate risk categories and 21 patients into the highintermediate and high-risk categories. According to the Hans' algorithm, patients were divided into two types: the germinal center B-cell (GCB) type $(n=40$, CD10 + or CD10-BCL6 + MUM1-) and non-GCB type $(\mathrm{n}=8$, CD10-BCL6- or CD10-BCL6+MUM1+), by semi-quantitatively scoring the fraction of tumor cells stained using a $30 \%$ threshold [16]. Based on the cell of origin, 40 patients $(83.3 \%)$ were of the GCB type.
Immunohistochemistry (IHC) was performed using formalin-fixed paraffin-embedded breast tissue biopsies prepared at the time of diagnosis. All cases were positive for C-MYC protein. 43 cases were both positive for BCL2 and BCL6 protein. 3 cases were only positive for BCL2 and 2 cases were only positive for BCL6. Chromosomal abnormalities were observed in 12 of 48 patients. 38 patients $(79.2 \%)$ were investigated with FISH for C-MYC and BCL2 translocations, while the remaining 10 patients were detected with FISH for C-MYC and BCL6 translocations. Next-generation sequencing (NGS)-based technologies was applied in 14 samples to identify lymphoma-specific genetic aberrations. 4 patients were found with TP53 gene mutation, 2 with BCL6 mutation, 2 with BCL2 mutation, 2 with CD79B, 2 with IGHD mutation, and the remaining cases were mutations related to unclear clinical significance. 14 patients were treated with DA-EPOCH-R/ MA, 16 patients were treated with R-HyperCVAD, and 18 patients were treated with DA-EPOCH-R. Eighteen patients underwent autologous stem cell transplantation (ASCT) after the initial therapy. After a median follow-up of 47 months (range, 9.5-79 months), 28 patients died. The causes of death were infectionrelated $(n=7)$, disease progression $(n=16)$, second malignancy $(n=2)$, and non-treatment-related $(n=2)$, and transplant-related $(\mathrm{n}=1)$.

\section{Treatment and efficacy}

The treatment options are summarised in Table 2, and the regimen doses are outlined in Table 3. Rituximabcontaining chemical regimens were scheduled to be administered to all patients. R-HyperCVAD was used in 16 cases, DA-EPOCH-R in 18 cases, and DA-EPOCH-R/ $\mathrm{MA}$ in 14 cases. In the R-HyperCVAD subgroup, 12 of 16 patients were treated with $A$ and $B$ regimens and the median cycles were 4 . After the median cycles of 3 cycles, 4 patients discontinued alternating $\mathrm{A}$ and $\mathrm{B}$ cycles in the last few courses owing to poor tolerance and severe bone marrow suppression. There were nine CR cases and two PR cases, and the ORR was $68.8 \%$. In the DAEPOCH-R subgroup, five of 18 patients underwent the DA-EPOCH-R regimen for 4-5 treatment cycles with the median cycles of 4 , and the rest underwent $6-8$ cycles with the median cycles of 7 . There were eight CR cases and three PR cases, and the ORR was $61.1 \%$. In the DAEPOCH-R/MA subgroup, 10 of 14 patients received 7-8 treatment cycles, and four received 4-6 cycles. There were seven CR cases and two PR cases, and the ORR was $64.3 \%$. More importantly, 4 patients with TP53 mutation all obtained PR even after high-dose of chemotherapy, and one of them co-occurrence with complex karyotypes relapse after ASCT. 
Table 1 Clinical characteristics of PB-DHL patients $(n=48)$

\begin{tabular}{|c|c|c|c|c|}
\hline Variable & $\begin{array}{l}\text { DA-EPOCH-R/MA } \\
(\mathrm{n}, \%)\end{array}$ & $\begin{array}{l}\text { DA-EPOCH-R } \\
(n, \%)\end{array}$ & $\begin{array}{l}\text { R-HyperCVAD } \\
(\mathrm{n}, \%)\end{array}$ & P value \\
\hline Age & & & & 0.711 \\
\hline$\leq 50$ years & $9(64.3)$ & $9(50.0)$ & $10(62.5)$ & \\
\hline $50-60$ years & $5(35.7)$ & $9(50.0)$ & $6(37.5)$ & \\
\hline Laterality & & & & 0.965 \\
\hline Right & $4(28.6)$ & $7(38.9)$ & $5(31.3)$ & \\
\hline Left & $7(50.0)$ & $8(44.4)$ & $7(43.8)$ & \\
\hline Bilateral & $3(21.4)$ & $3(16.7)$ & $4(25.0)$ & \\
\hline Tumour size & & & & 0.811 \\
\hline$<5 \mathrm{~cm}$ & $8(57.1)$ & $11(61.1)$ & $11(68.8)$ & \\
\hline$\geq 5 \mathrm{~cm}$ & $6(42.9)$ & $7(38.9)$ & $5(31.3)$ & \\
\hline Cell of origin & & & & 0.890 \\
\hline GCB & $11(78.6)$ & $15(83.3)$ & $14(87.5)$ & \\
\hline Non-GCB & $3(21.4)$ & $3(16.7)$ & $2(12.5)$ & \\
\hline Results of FISH & & & & 0.745 \\
\hline MYC-BCL2 & $10(71.4)$ & $15(83.3)$ & $13(81.3)$ & \\
\hline MYC-BCL6 & $4(28.6)$ & $3(16.7)$ & $3(18.8)$ & \\
\hline C-MYC of IHC & & & & 1.000 \\
\hline C-MYC (+) & $14(100.0)$ & $18(100.0)$ & $16(100.0)$ & \\
\hline $\mathrm{BCL} 2$ of IHC & & & & 0.521 \\
\hline $\mathrm{BCL} 2(+)$ & $13(92.9)$ & $18(100.0)$ & 15 (93.8) & \\
\hline BCL6 of IHC & & & & 0.767 \\
\hline BCL6 (+) & $14(100.0)$ & $16(88.9)$ & $15(93.8)$ & \\
\hline CD5 of IHC & & & & 0.406 \\
\hline CD5 (+) & $5(35.7)$ & $4(22.2)$ & $7(43.8)$ & \\
\hline CD10 of IHC & & & & 0.661 \\
\hline CD10 (+) & $10(71.4)$ & $10(55.6)$ & $9(56.3)$ & \\
\hline P53 of IHC & & & & 0.926 \\
\hline P53 (+) & $9(64.3)$ & $13(72.2)$ & $11(68.8)$ & \\
\hline $\mathrm{Ki}-67$ of $\mathrm{IHC}$ & & & & 0.668 \\
\hline $\mathrm{Ki}-67 \geq 70 \%$ & $12(85.7)$ & $17(94.4)$ & 15 (93.8) & \\
\hline Chromosomal abnormality & & & & 0.700 \\
\hline Present & $3(21.4)$ & $6(33.3)$ & $3(18.8)$ & \\
\hline Ann Arbor Staging & & & & 0.832 \\
\hline IE & $4(28.6)$ & $6(33.3)$ & $3(18.8)$ & \\
\hline$\| \mathrm{E}$ & $7(50.0)$ & $7(38.9)$ & $7(43.8)$ & \\
\hline IV & $3(21.4)$ & $5(27.8)$ & $6(37.5)$ & \\
\hline B symptoms & & & & 0.652 \\
\hline Present & $10(71.4)$ & $10(55.6)$ & $10(62.5)$ & \\
\hline LDH level & & & & 0.544 \\
\hline Elevated & $5(35.7)$ & $7(38.9)$ & $9(56.3)$ & \\
\hline Risk stratification & & & & 0.665 \\
\hline $\mathrm{L}$ and $\mathrm{L}-\mathrm{I}$ & $9(64.3)$ & $9(50.0)$ & $9(56.3)$ & \\
\hline $\mathrm{H}$ and $\mathrm{H}-\mathrm{I}$ & $5(35.7)$ & $9(50.0)$ & $7(43.8)$ & \\
\hline ASCT & & & & 0.811 \\
\hline Yes & $6(42.9)$ & $7(38.9)$ & $5(31.3)$ & \\
\hline
\end{tabular}

$P B-D H L$ primary breast double-hit lymphoma, $R$-HyperCVAD rituximab, hyperfractionated cyclophosphamide, vincristine, doxorubicin, dexamethasone, alternating with cytarabine plus methotrexate, $D A-E P O C H-R$ rituximab, dose-adjusted etoposide, prednisone, vincristine, cyclophosphamide, doxorubicin, $D A-E P O C H-R /$ $M A$ rituximab, dose-adjusted etoposide, prednisone, vincristine, cyclophosphamide, doxorubicin, alternating with high-dose methotrexate and cytarabine, FISH fluorescence in situ hybridization, IHC immunohistochemistry, $L D H$ lactate dehydrogenase, $G C B$ germinal centre B-cell, $L$ low risk, $L-/$ low-intermediate risk $H-I /$ highintermediate risk, $H$ high risk, ASCT autologous stem cell transplantation 
Table 2 Summary of treatment

\begin{tabular}{ll}
\hline Treatment strategy & PB-DHL, N (\%) \\
\hline $\begin{array}{l}\text { Breast irradiation } \\
\text { Sequence of breast irradiation }\end{array}$ & $31(64.6)$ \\
Breast irradiation with concurrent chemotherapy & $11(22.9)$ \\
Breast irradiation following chemotherapy & $20(41.7)$ \\
Chemotherapy protocol & \\
R-HyperCVAD & $16(33.3)$ \\
DA-EPOCH-R & $18(37.5)$ \\
DA-EPOCH-R/MA & $14(29.2)$ \\
ASCT & $18(37.5)$ \\
\hline
\end{tabular}

$P B-D H L$ primary breast double-hit lymphoma, $R$-HyperCVAD rituximab, hyperfractionated cyclophosphamide, vincristine, doxorubicin, dexamethasone, alternating with cytarabine plus methotrexate, $D A-E P O C H-R$ rituximab, doseadjusted etoposide, prednisone, vincristine, cyclophosphamide, doxorubicin $D A-E P O C H-R / M A$ rituximab, dose-adjusted etoposide, prednisone, vincristine, cyclophosphamide, doxorubicin, alternating with high-dose methotrexate and cytarabine, ASCT autologous stem cell transplantation

ASCT was performed in 18 patients, with 6 cases in DA-EPOCH-R/MA group, 7 cases in DA-EPOCH$\mathrm{R}$ group, and 5 cases in R-HyperCVAD group. Before ASCT, 13 patients achieved CR, in which 9 were first complete remission (CR1) and 4 were second complete remission (CR2). No significant differences of prognosis were found among CR1 and CR2 patients following ASCT $(\mathrm{P}>0.05)$.

Breast irradiation was performed in 31 of 48 patients (64.6\%) with a median dose of 30 Gy. Twenty patients received breast irradiation following chemotherapy and 11 received breast irradiation with concurrent chemotherapy. The breast radiotherapy sequence did not affect ORR $(\mathrm{P}>0.05)$. None of the patients underwent contralateral breast or cranial radiotherapy.

All patients received the prophylactic CNS strategy; 26 received intrathecal chemoprophylaxis 6-8 times, and 22 received intrathecal chemoprophylaxis 4-5 times. Kaplan-Meier survival analysis showed that the intrathecal chemoprophylaxis time did not affect long-term survival. MA-containing regimen (R-HyperCVAD or DA-EPOCH-R/MA) was administered in 30 cases. Given that MA regimen has achieved CNS prophylaxis, intrathecal chemoprophylaxis wasn't applied to patients any more during the chemotherapy of MA.

\section{Toxic effects}

Information on toxic effects was recorded and assessed based on the WHO's Common Toxicity Criteria; haematologic toxicity was the most common adverse effect. Grade 3/4 myelosuppression in the R-HyperCVAD subgroup was more severe than that in the DA-EPOCH-R and DA-EPOCH-R/MA subgroups (Fisher's exact test; $75 \%$ vs. $16.7 \%$ vs. $28.6 \%$, respectively; $\mathrm{P}=0.001$ ). Other toxic effects, such as liver and kidney function damage, gastrointestinal reactions, haemorrhage, and cardiotoxicity, were mild and manageable, and the differences were insignificant. These side effects returned to normal after a short period of symptomatic and supportive treatment.

\section{Survival analysis}

The univariate and multivariate analyses of prognostic factors are outlined in Table 4. The median OS was $29.0 \pm 7.2$ months (95\% CI, 14.9-43.1 months) and the median PFS was 25.0 \pm 8.5 months (95\% CI, 8.3-41.7 months). As shown in Fig. 2, the overall five-year OS and PFS were $41.7 \%$ (95\% CI, 27.6-56.8\%) and 37.5\% (95\% CI, 24.0-52.6\%), respectively. The potentially significant factors from the univariate analysis $(\mathrm{P}<0.1)$ included laterality, tumour size, the Ann Arbor staging classification, risk stratification, B symptoms, chemical regimens, breast radiotherapy, and ASCT and were included in the multivariate analysis. Multivariate analysis with the Cox proportional-hazards model identified tumour size (Fig. 3A, B), risk stratification (Fig. 3C, D), treatment with DA-EPOCH-R/MA (Fig. 4), breast radiotherapy (Fig. 5A, B), and ASCT (Fig. 5C, D) as independent prognostic factors.

\section{Disease relapse}

Disease relapse occurred in 18 patients; three patients without breast irradiation had contralateral breast relapse, seven patients had CNS relapse, and eight patients had lymph node relapse.

The CNS recurrence rate was $10 \%$ in patients who received the MA-containing regimen and $22.2 \%$ in patients who did not $(\mathrm{P}>0.05)$. In contrast, $\mathrm{CNS}$ did not progress in any patient following ASCT, but $23.3 \%$ of patients who did not receive ASCT had progression. Therefore, ASCT was associated with a significantly decreased risk of early CNS progression $(\mathrm{P}=0.036)$.

Contralateral breast tissue was the second most involved extranodal site. In this cohort, three patients without breast irradiation experienced contralateral breast relapse, including one with contralateral breast relapse occurring during salvage therapy. Tumour size and axillary lymph nodes were not related to the recurrence of the contralateral breast in this cohort.

\section{Discussion}

PB-DHL is rare but deserves discussion because its biological characteristics are quite different from those of the more typical B-cell lymphoma [4]. PB-DHL typically presents in the 50 or $60 \mathrm{~s}$ as a painless, solitary, palpable breast lump, indistinguishable from breast cancer [5]. Previous studies identified that PB-DHL predominantly occurs in women, commonly perimenopausal women. 
Table 3 Therapeutic regimens

\begin{tabular}{|c|c|c|}
\hline Regimens & Dose & $\begin{array}{l}\text { Days of } \\
\text { administration }\end{array}$ \\
\hline \multicolumn{3}{|l|}{ R-HyperCVAD regimen } \\
\hline \multicolumn{3}{|l|}{ Cycle A } \\
\hline Rituximab & $375 \mathrm{mg} / \mathrm{m}^{2}$ & 1 \\
\hline Cyclophosphamide & $300 \mathrm{mg} / \mathrm{m}^{2}$ every $12 \mathrm{~h}$ & $2-4$ \\
\hline Vincristine & $1.4 \mathrm{mg} / \mathrm{m}^{2}$ & 4,11 \\
\hline Doxorubicin & $50 \mathrm{mg} / \mathrm{m}^{2}$ & 4 \\
\hline Dexamethasone & 40 mg per day & $1-4,11-14$ \\
\hline \multicolumn{3}{|l|}{ Cycle B } \\
\hline Rituximab & $375 \mathrm{mg} / \mathrm{m}^{2}$ & 1 \\
\hline Methotrexate & $1 \mathrm{~g} / \mathrm{m}^{2}$ continuous intravenous infusion for $24 \mathrm{~h}$ & 2 \\
\hline Cytarabine & $3 \mathrm{~g} / \mathrm{m}^{2}$ every $12 \mathrm{~h}$ & 3,4 \\
\hline \multicolumn{3}{|c|}{ DA-EPOCH-R regimen ${ }^{a}$} \\
\hline Rituximab & $375 \mathrm{mg} / \mathrm{m}^{2}$ & 1 \\
\hline Etoposide & $50 \mathrm{mg} / \mathrm{m}^{2}$ continuous intravenous infusion for $24 \mathrm{~h}$ & $2-5$ \\
\hline Doxorubicin & $10 \mathrm{mg} / \mathrm{m}^{2}$ continuous intravenous infusion for $24 \mathrm{~h}$ & $2-5$ \\
\hline Vincristine & $0.4 \mathrm{mg} / \mathrm{m}^{2}$ continuous intravenous infusion for $24 \mathrm{~h}$ & $2-5$ \\
\hline Cyclophosphamide & $750 \mathrm{mg} / \mathrm{m}^{2}$ & 6 \\
\hline Prednisone & $60 \mathrm{mg} / \mathrm{m}^{2}$ & $2-6$ \\
\hline \multicolumn{3}{|c|}{ DA-EPOCH-R/MA regimen } \\
\hline \multicolumn{3}{|l|}{ DA-EPOCH-R } \\
\hline Rituximab & $375 \mathrm{mg} / \mathrm{m}^{2}$ & 1 \\
\hline Etoposide & $50 \mathrm{mg} / \mathrm{m}^{2}$ continuous intravenous infusion for $24 \mathrm{~h}$ & $2-5$ \\
\hline Doxorubicin & $10 \mathrm{mg} / \mathrm{m}^{2}$ continuous intravenous infusion for $24 \mathrm{~h}$ & $2-5$ \\
\hline Vincristine & $0.4 \mathrm{mg} / \mathrm{m}^{2}$ continuous intravenous infusion for $24 \mathrm{~h}$ & $2-5$ \\
\hline Cyclophosphamide & $750 \mathrm{mg} / \mathrm{m}^{2}$ & 6 \\
\hline Prednisone & $60 \mathrm{mg} / \mathrm{m}^{2}$ & $2-6$ \\
\hline \multicolumn{3}{|l|}{ Alternating with MA } \\
\hline Methotrexate & $3 \mathrm{~g} / \mathrm{m}^{2}$ & 1 \\
\hline Cytarabine & $2 \mathrm{~g} / \mathrm{m}^{2}$ every $12 \mathrm{~h}$ & $2-3$ \\
\hline \multicolumn{3}{|l|}{ Intrathecal prophylaxis } \\
\hline Methotrexate & $10 \mathrm{mg}$ & \\
\hline Dexamethasone & $10 \mathrm{mg}$ & \\
\hline Cytarabine & $50 \mathrm{mg}$ & \\
\hline
\end{tabular}

PB-DHL primary breast double-hit lymphoma, $R$-HyperCVAD rituximab, hyperfractionated cyclophosphamide, vincristine, doxorubicin, dexamethasone, alternating with cytarabine plus methotrexate, $D A-E P O C H-R$ rituximab, dose-adjusted etoposide, prednisone, vincristine, cyclophosphamide, doxorubicin, $D A-E P O C H-R / M A$, rituximab, dose-adjusted etoposide, prednisone, vincristine, cyclophosphamide, doxorubicin, alternating with high-dose methotrexate and cytarabine, $M A$ high-dose methotrexate and cytarabine, $I V$ intravenous infusion

${ }^{a}$ The doses of etoposide, doxorubicin, and cyclophosphamide were adjusted according to criteria [23, 35]

However, some reports have included male patients [17, 18]. In this study, all cases were women, consistent with other reports.

Immunochemotherapy combined with breast radiotherapy is the currently recognised first-line therapy for PBL [2]. Research over the past decades has identified that surgical treatment offers little benefit to long-term prognosis and is no longer the mainstream of treatment $[6,13]$. In this study, surgery was only employed for excisional biopsies rather than for treatment. The role of radiotherapy was clarified in clinical trials during the prerituximab era [19], but the benefits of radiotherapy for PB-DHL patients receiving rituximab-containing regimens remains controversial. The research indicates that immunochemotherapy alone was insufficient to achieve excellent control of local tumours, and the combination of radiotherapy and chemotherapy had the strongest benefit before ASCT. Breast irradiation also contributed to durable remission with improved OS and PFS, justifying its consideration for high-risk young patients. Relevant 


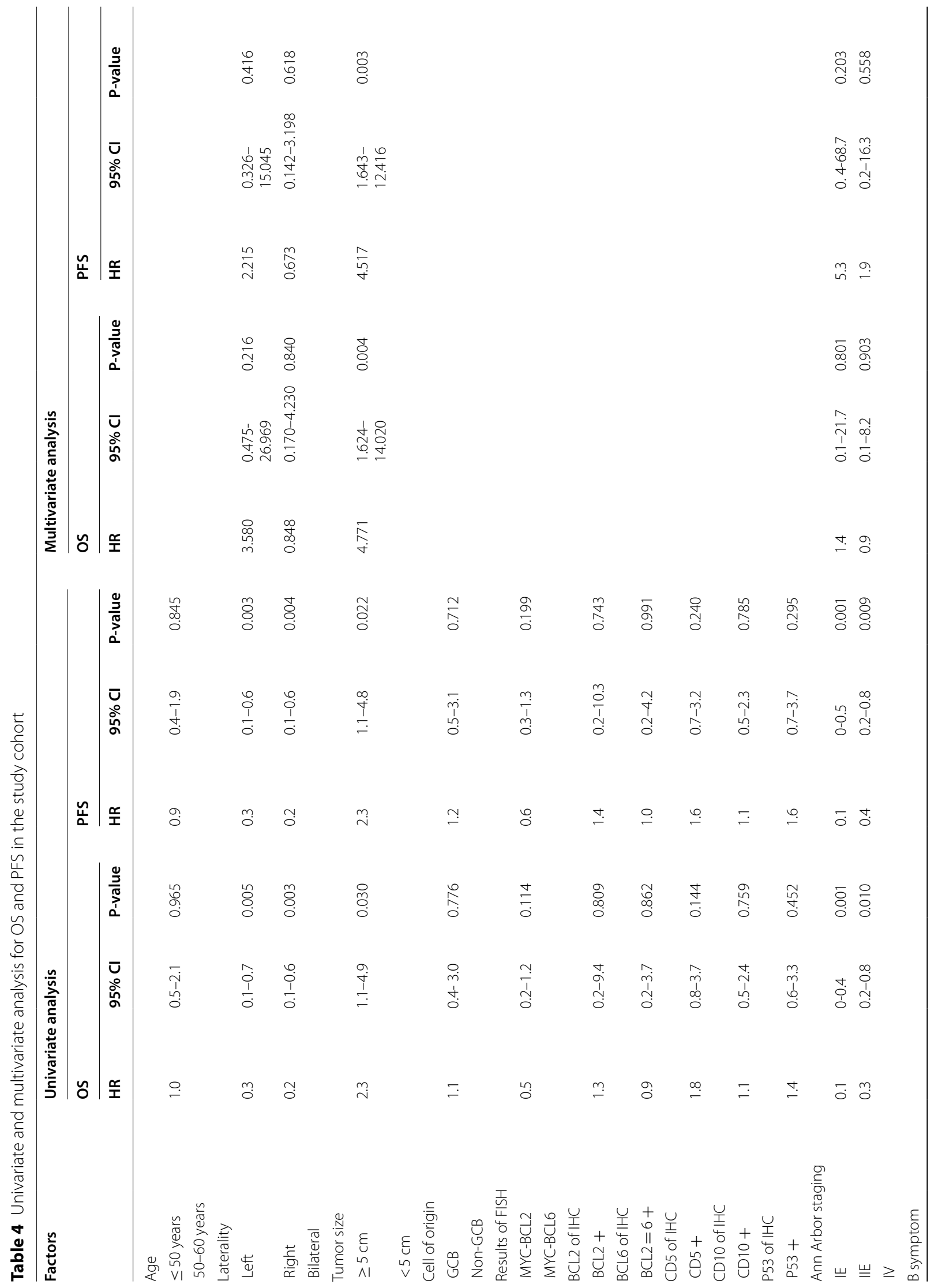




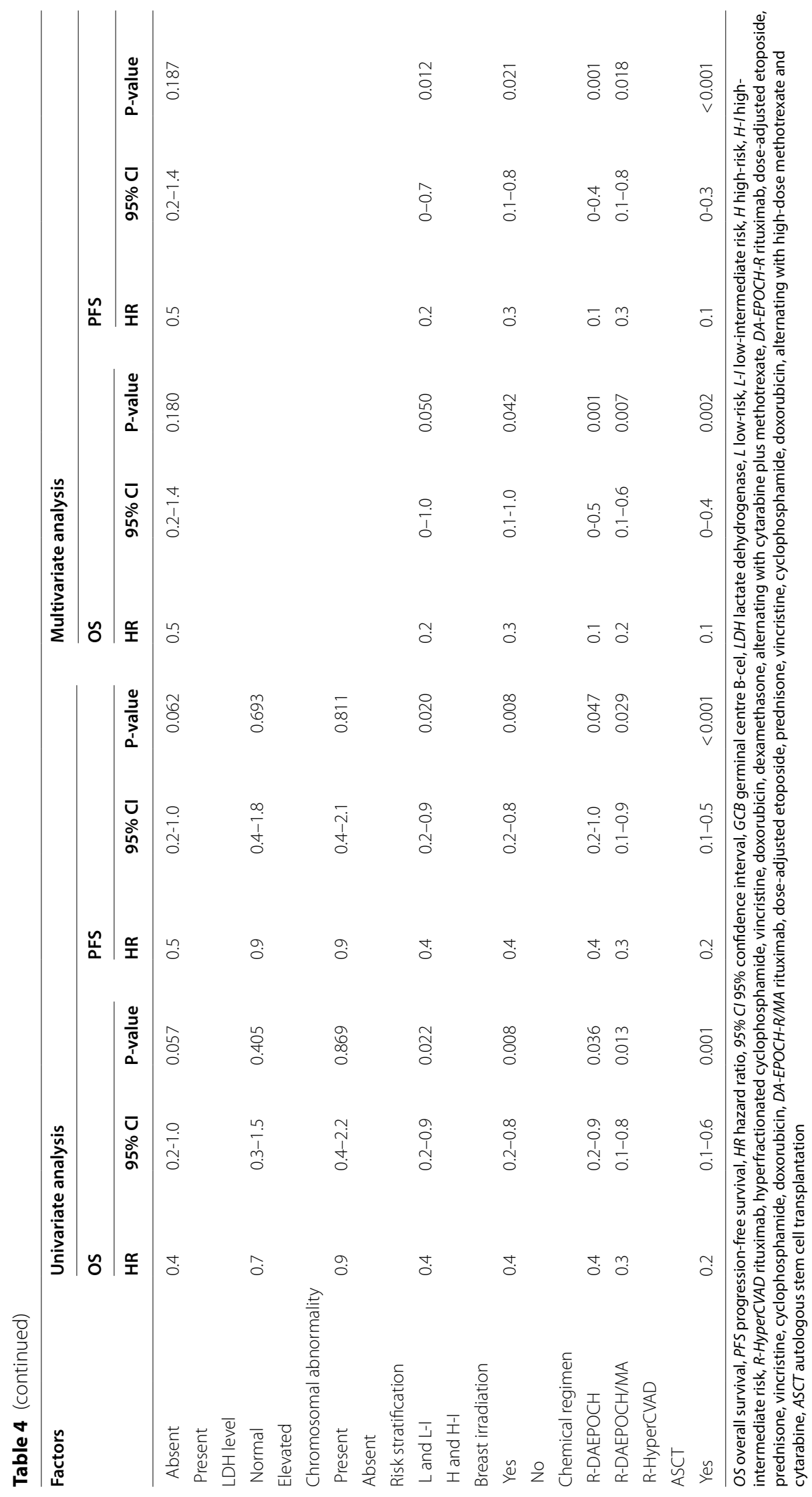




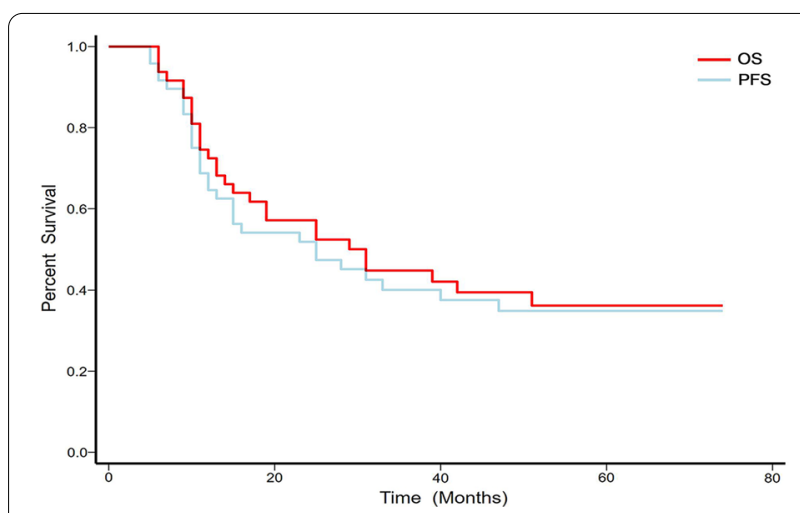

Fig. 2 The Kaplan-Meier overall (A) and progression-free (B) survival curves

observations have also highlighted the beneficial effects of radiotherapy in PBL patients treated with rituximabbased regimens, which compensated for the deficiency of immunochemotherapy in the local control of residual disease or recurrence [20]. A median breast irradiation dose of 30 Gy is widely recommended $[2,3,6]$.

Because there are no standard guidelines for PB-DHL [21], making an accurate diagnosis and choosing optimal regimens is challenging [22, 23]. This research showed that the efficacy benefits of the three treatment schemes were not significant, but the DA-EPOCH-R/ MA group had the best survival outcomes, followed by the DA-EPOCH-R group. Although the R-HyperCVAD remission rate was slightly higher than that of the other two groups, severe bone marrow suppression might lead to treatment interruption, hampering its application. Kieron et al. [24] conducted a prospective Phase II study of DA-EPOCH-R in aggressive B-cell lymphoma with MYC rearrangement and emphasised that the DAEPOCH-R regimen produced durable remission and could be applied for treating aggressive B-cell lymphoma. The Spanish PETHEMA group [25] conducted a Phase II study of DA-EPOCH-R in untreated patients with poor prognosis for large B-cell lymphoma and stressed that DA-EPOCH-R showed an excellent outcome with a tolerable toxicity profile in high-risk large B-cell lymphoma patients. We also found that the DA-EPOCH-R group had a lower myelosuppression risk than the R-HyperC$\mathrm{VAD}$, suggesting that DA-EPOCH-R was relatively safe and well-tolerated. The DA-EPOCH-R/MA regimen, based on DA-EPOCH-R, initially exhibited satisfactory five-year OS and PFS outcomes, indicating that highdose methotrexate and cytarabine can consolidate the efficacy of DA-EPOCH-R to some extent.

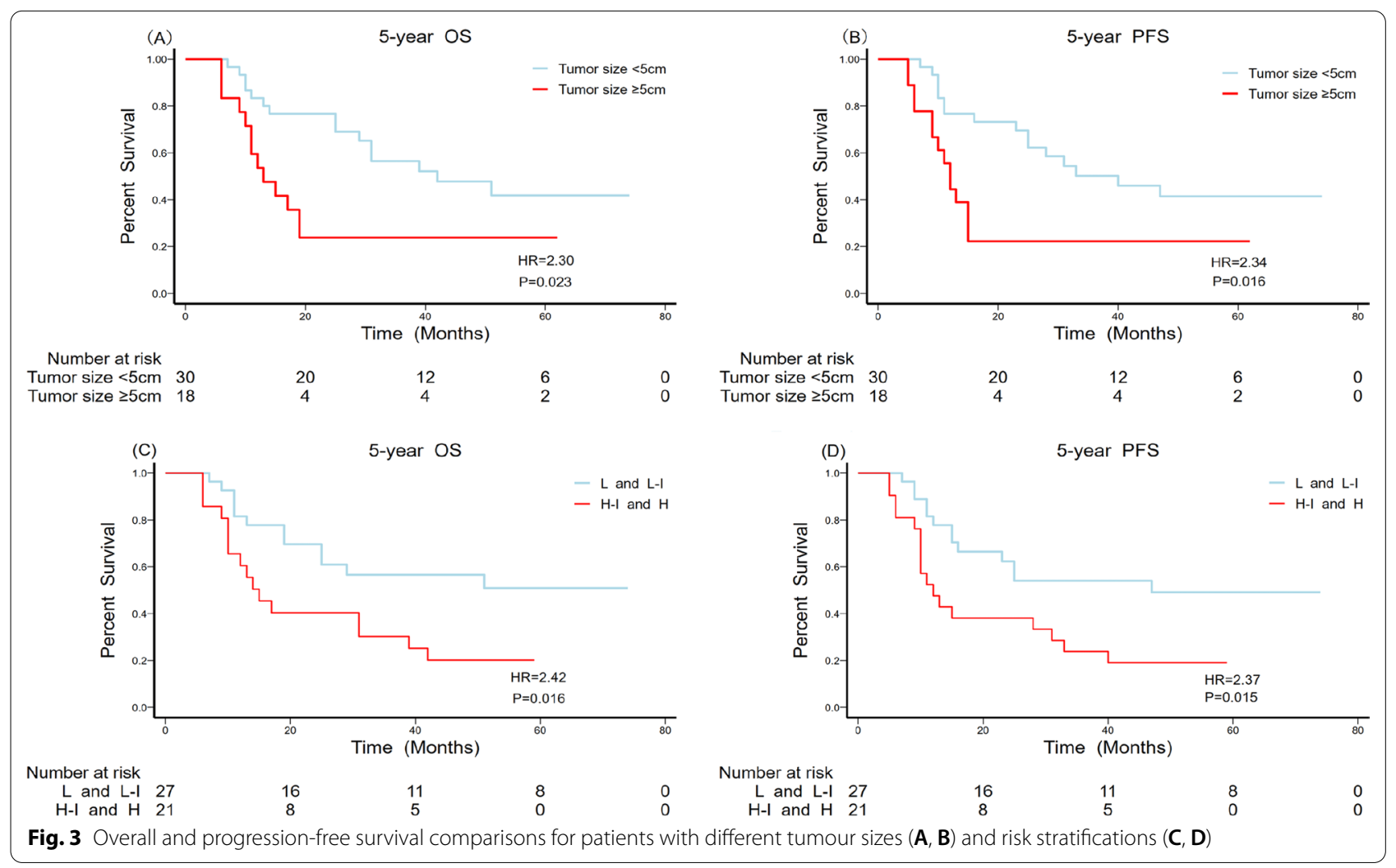




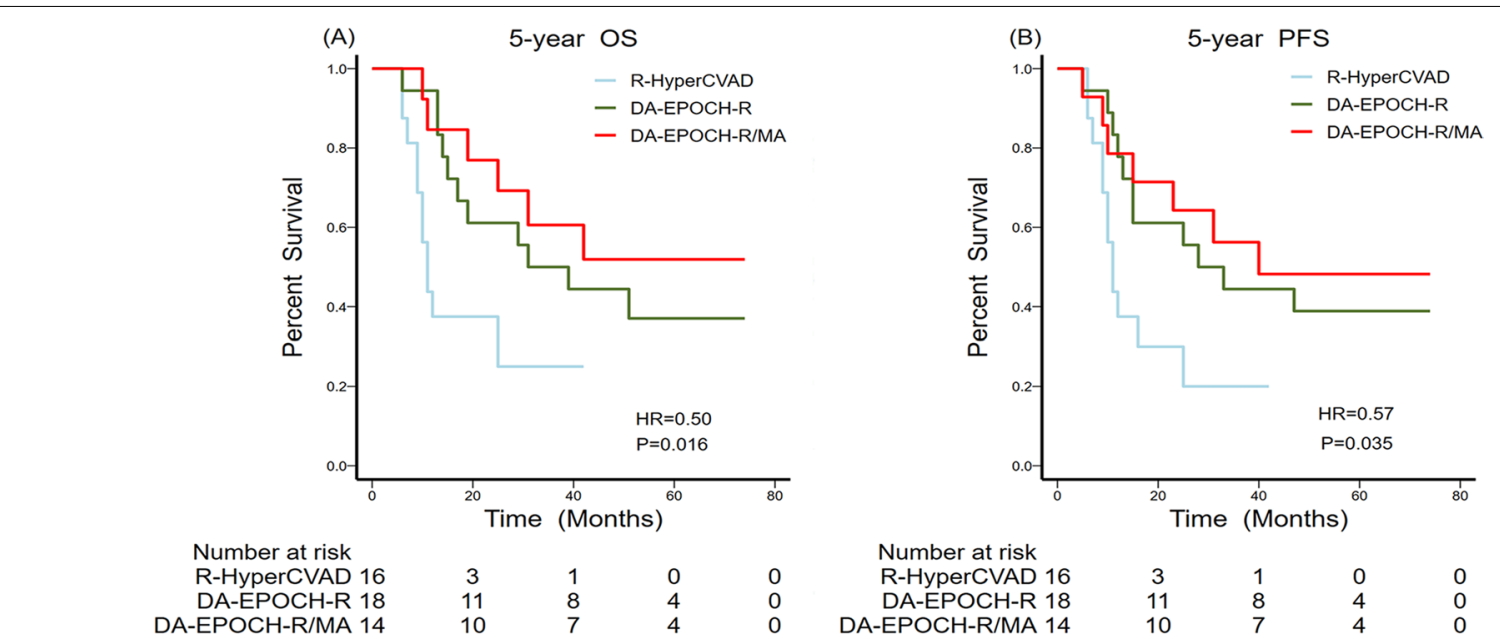

Fig. 4 Overall (A) and progression-free (B) survival comparisons among the three treatment regimens

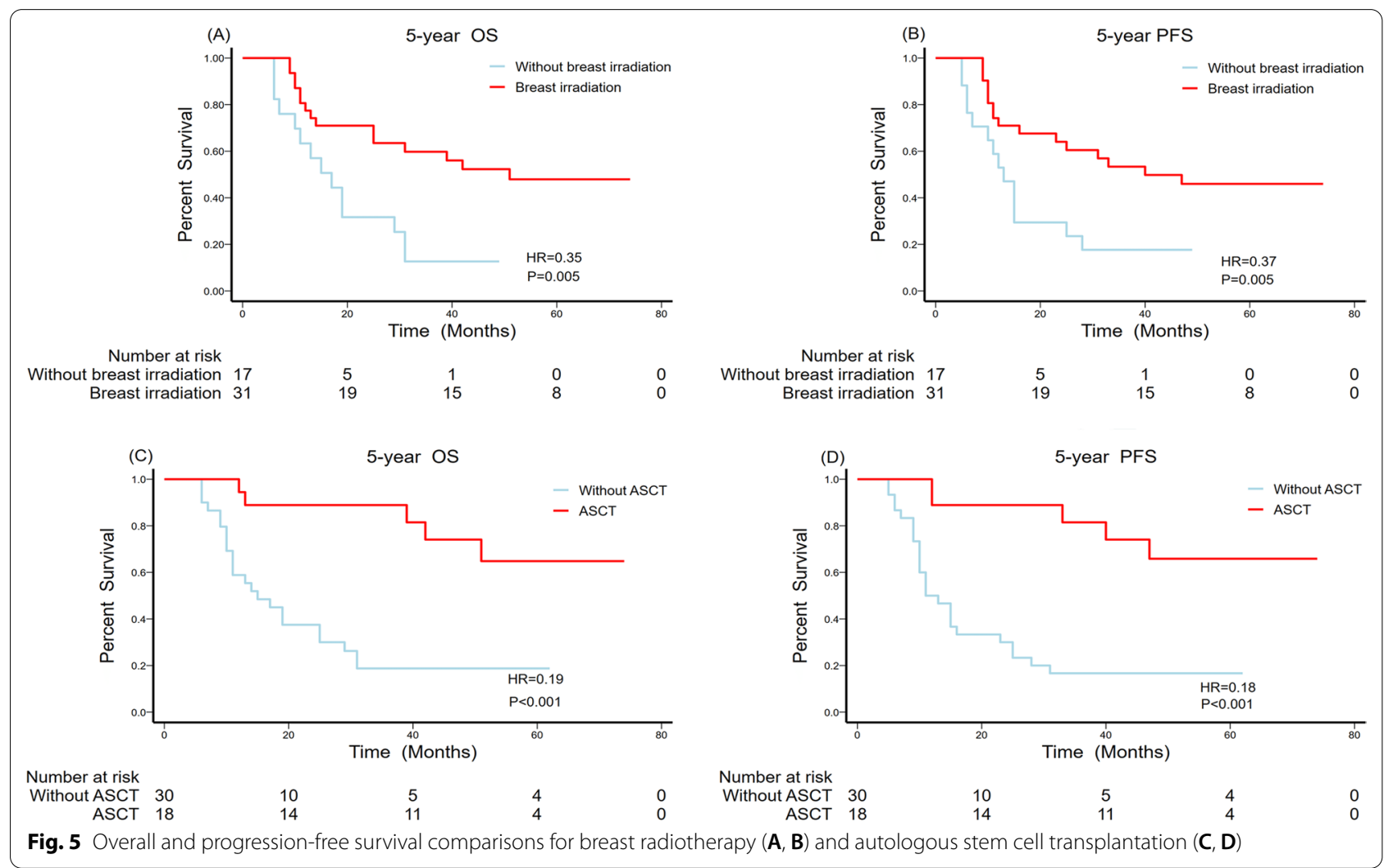

CNS relapse is a common and devastating complication of PB-DHL, and the CNS relapse rate is much higher than that of PBL-DLBCL [26]. To date, the underlying CNS progression mechanism is unknown, and prophylactic strategies have become an integral part of current treatment protocols [27]. Common prophylactic CNS strategies for PB-DHL included intrathecal chemoprophylaxis and systemic CNS penetrants such as methotrexate [28]. Depending on previous research, CNS relapse mainly involves the brain parenchyma, and leptomeningeal involvement is rare. Thus, intrathecal chemoprophylaxis, which does not adequately penetrate the brain parenchyma, insufficiently prevents parenchymal CNS recurrence [28, 29]. Holte et al. [30] conducted 
a study of 156 eligible patients with aggressive B-cell lymphomas and implemented a high-dose of cytarabine plus methotrexate regimen (MA regimen) to reduce the incidence of CNS-related events. The results showed a satisfactory CNS relapse rate of $4.5 \%$, which is much lower than that in other published reports. Considering that high-dose methotrexate and cytarabine can penetrate the blood-brain barrier, the risk of CNS progression could be further reduced [31, 32]. The MA regimen was expected to reduce the risk of CNS progression, but, in this series, the MA regimen was not superior for CNS prophylaxis in PB-DHL. As a result, the prevention of CNS progression depending on chemotherapy alone was insufficient. In contrast, CNS progression was not detected after ASCT, and more durable remission was achieved in patients who received ASCT than in those who did not $(\mathrm{P}<0.001)$. Considering the fatal outcome of CNS relapse and the limited efficacy of high-dose chemotherapy, ASCT is strongly recommended to reduce the CNS relapse rate and prolong survival.

The contralateral breast tissue is the second most common recurrence site, except in the CNS [18]. This study's results indicated that breast radiotherapy was better for local control. The survival and relapse rates of patients who received concurrent chemotherapy or post-chemotherapy breast irradiation did not differ. Thus, the breast irradiation sequence of breast irradiation and chemotherapy remains ambiguous in this study. Breast irradiation produced durable remission, justifying its consideration in treating young patients with PB-DHL. If contralateral breast relapse occurred, the clinical outcomes were dismal with unsatisfactory salvage therapies [12]. Therefore, for high-risk young patients, the first-line treatment of PB-DHL patients could be to apply ASCT, despite ASCT not being the first-line treatment for lymphoma.

Since high-intensive chemotherapy alone is insufficient to induce long-term disease control, ASCT could be the most appropriate treatment method if CR or PR is attained, especially for high-risk young patients. ASCT may overcome the poor prognostic implications of this kind of aggressive disease subtype, and there is no doubt that young patients with excellent performance statuses and few comorbidities are the best candidates for ASCT. In this multicentre study, patients who received ASCT had significantly superior outcomes compared to those who did not, suggesting that ASCT greatly reduced the disease progression risk. Similarly, Kim et al. [33] explored a high dose of chemotherapy combined with ASCT for high-risk DLBCL patients and found that ASCT yielded superior OS and PFS. The three-year OS in the ASCT group was $85.0 \%$ and was $75.8 \%$ in the nonASCT group $(P=0.038)$. Further, the three-year PFS was also better in the ASCT group (76.6\% vs. $63.3 \%$;
$\mathrm{P}=0.007)$. To date, the ASCT status has not been challenged by high-intensity chemotherapy or novel targeted agents, and it remains an appropriate choice to abrogate the negative prognostic impact of PB-DHL [34]. Highdose chemotherapy followed by ASCT in an upfront setting currently remains the second-line treatment for DLBCL [35], and ASCT is the only feasible therapy offering a cure. Due to the limited efficacy of conventional chemotherapy, dynamic dose-adjusted chemotherapy supported by ASCT should be administered to young PB-DBL patients [36, 37]. The ASCT results showed excellent efficacy and durable remission among patients with $C R$ in a pre-transplantation setting, which is an important initial step for developing ASCT as a first-line treatment strategy for highly aggressive PB-DHL. To further assess the long-term prognosis, a larger-scale investigation that includes more patients receiving ASCT is should be conducted in the future.

TP53 mutations have been shown to be significantly associated with poor overall survival in DLBCL [38, 39]. Clipson A et al. [40] also found the significant association of TP53 mutation with poor overall survival in DLBCL with MYC translocation. In line with this, four cases with TP53 mutation in this research were found to be more refractory to high-dose of chemotherapy and more likely to relapse than those without TP53 mutation. Therefore, new frontline therapeutic combinations including novel target drugs such as BCL-2 inhibitor have shown promising results [41]. Nonetheless, the number of TP53 mutation cases investigated in this study is small and the distinct impact of TP53 mutation in PB-HGBCL remains to be elucidated.

\section{Limitations}

Major limitations of this study include the relatively small sample size and retrospective nature. The sample size may have limited our ability to detect significant differences. Additionally, follow-up for the evaluation of other complications, including secondary malignancies, was short. Nevertheless, considering the rarity of PB-DHL and the lack of a previously published cohort study, the results of this study still have great guiding significance (Additional file 1).

\section{Conclusions}

This multicentre North-China collaboration provides insights into effective therapeutic management and failure patterns of PB-DHL. DA-EPOCH-R/MA was a promising regimen for $\mathrm{PB}-\mathrm{DHL}$, and breast irradiation yielded complementary benefits for relapse reduction. Notably, ASCT significantly decreased disease relapse and provided a potential curative PB-DHL intervention, justifying ASCT as a first-line therapy for young patients. 
The exploration of more effective treatment strategies for patients with PB-DHL remains promising.

\section{Supplementary Information}

The online version contains supplementary material available at https://doi. org/10.1186/s12935-021-02198-y.

Additional file 1. Original data.

\section{Acknowledgements}

We acknowledge the Affiliated Hospital of Qingdao University, Qingdao Central Hospital, Yuhuangding Hospital of Yantai, Linyi Central Hospital, Weihai Municipal Hospital. This work was supported by the Youth Program of National Natural Science Foundation of China (No. 81900182).

\section{Author's contributions}

SF and YS conceived and designed the research study. YZ and HF performed the research. TZ wrote the first draft of the manuscript and analysed the data. LW and XS provided input on data analysis and critically revised the manuscript. PW and JY supervised the research. The final version of this manuscript was approved by all authors. All authors read and approved the final manuscript.

\section{Funding}

This work was supported by the Youth Program of National Natural Science Foundation of China (No. 81900182).

\section{Availability of data and materials}

All the original data used in this article is available from the corresponding authors on reasonable request.

\section{Declarations}

\section{Ethics approval and consent to participate}

Data collection was approved by the Ethics Committee of Chinese Academy of Hematology and Blood Diseases Hospital.

\section{Consent for publication}

Not applicable.

\section{Competing interests}

All authors declared no competing interests.

\section{Author details}

${ }^{1}$ Haematopoietic Stem Cell Transplantation Centre, State Key Laboratory of Experimental Hematology, National Clinical Research centre for Blood Diseases, Institute of Hematology and Blood Diseases Hospital, Chinese Academy of Medical Sciences and Peking Union Medical College, No. 288 Nanjing Road, Tianjin 300020, China. ${ }^{2}$ Department of Haematology, The Affiliated Yantai Yuhuangding Hospital of Qingdao University, Yantai 264000, Shandong, China. ${ }^{3}$ Department of Haematology, The Affiliated Hospital of Qingdao University, Qingdao 266003, Shandong, China. ${ }^{4}$ Department of Haematology, Shengli Oilfield Central Hospital, Dongying 257000, China. ${ }^{5}$ Department of Haematology, Qingdao Centre Hospital, Qingdao 266042, Shandong, China. ${ }^{6}$ Department of Haematology, Weihai Municipal Hospital, Weihai 264200, Shandong, China.

Received: 10 June 2021 Accepted: 6 September 2021

Published online: 17 September 2021

\section{References}

1. Cheah CY, Campbell BA, Seymour JF. Primary breast lymphoma. Cancer Treat Rev. 2014;40:900-8.

2. Jia Y, Sun C, Liu Z, Wang W, Zhou X. Primary breast diffuse large B-cell lymphoma: a population-based study from 1975 to 2014 . Oncotarget. 2018;9:3956-67.
3. Shao YB, Sun XF, He YN, Liu CJ, Liu H. Clinicopathological features of thirty patients with primary breast lymphoma and review of the literature. Med Oncol. 2015;32:448.

4. Wiseman C, Liao KT. Primary lymphoma of the breast. Cancer. 1972;29:1705-12.

5. Avilés A, Castañeda C, Neri N, Cleto S, Nambo MJ. Rituximab and dose dense chemotherapy in primary breast lymphoma. Haematologica. 2007;92:1147-8.

6. Zhao S, Zhang QY, Ma WJ, Zhang MH, Sun WZ, Li HB, Zhang XS, Di WY, Wang XC. Analysis of 31 cases of primary breast lymphoma: the effect of nodal involvement and microvascular density. Clin Lymphoma Myeloma Leuk. 2011;11:33-7.

7. Wadhwa A, Senebouttarath K. Primary lymphoma of the breast: a case series. Radiol Case Rep. 2018;13:815-21.

8. Thomas A, Link BK, Altekruse S, Romitti PA, Schroeder MC. Primary breast lymphoma in the United States: 1975-2013. J Natl Cancer Inst. 2017:109.

9. Sesques P, Johnson NA. Approach to the diagnosis and treatment of high-grade B-cell lymphomas with MYC and BCL2 and/or BCL6 rearrangements. Blood. 2017;129:280-8.

10. Davies A. Double-hit lymphoma: so what? Hematol Oncol. 2019;37(Suppl 1):19-23.

11. Eyre TA. Another disappointment in treating relapsed, refractory high-risk aggressive B-cell lymphomas. Br J Haematol. 2020;188:202-4.

12. Franco Pérez F, Lavernia J, Aguiar-Bujanda D, Miramón J, Gumá J, Álvarez R, Gómez-Codina J, Arroyo FG, Llanos M, Marin M, Alfaro J, Quero C, Delgado M, Nogales E, Menarguez F, Martinez N, Torrente M, Royuela A. Abreu D and Provencio M. Primary breast lymphoma: analysis of 55 cases of the Spanish lymphoma oncology group. Clin Lymphoma Myeloma Leuk. 2017;17:186-91.

13. Zhang N, Cao C, Zhu Y, Liu P, Liu L, Lu K, Luo J, Zhou N. Primary breast diffuse large B-cell lymphoma in the era of rituximab. Onco Targets Ther. 2016;9:6093-7.

14. Swerdlow SH, Campo E, Pileri SA, Harris NL, Stein H, Siebert R, Advani R, Ghielmini M, Salles GA, Zelenetz AD, Jaffe ES. The 2016 revision of the World Health Organization classification of lymphoid neoplasms. Blood. 2016;127:2375-90.

15. Cheson BD, Pfistner B, Juweid ME, Gascoyne RD, Specht L, Horning SJ, Coiffier B, Fisher RI, Hagenbeek A, Zucca E, Rosen ST, Stroobants S, Lister TA, Hoppe RT, Dreyling M, Tobinai K, Vose JM, Connors JM. Federico M and DiehI V. Revised response criteria for malignant lymphoma. J Clin Oncol. 2007;25:579-86.

16. Hans CP, Weisenburger DD, Greiner TC, Gascoyne RD, Delabie J, Ott G Müller-Hermelink HK, Campo E, Braziel RM, Jaffe ES, Pan Z, Farinha P, Smith LM, Falini B, Banham AH, Rosenwald A, Staudt LM, Connors JM, Armitage JO, Chan WC. Confirmation of the molecular classification of diffuse large B-cell lymphoma by immunohistochemistry using a tissue microarray. Blood. 2004;103:275-82.

17. Wei ZL, Huang DP. Advances in diagnosis and treatment of primary breast lymphoma—review. Zhongguo Shi Yan Xue Ye Xue Za Zhi. 2017;25:604-7.

18. Ludmir EB, Milgrom SA, Pinnix CC, Gunther JR, Westin J, Oki Y, Fayad LE, Medeiros LJ, Dabaja BS and Nastoupil LJ. Primary breast diffuse large B-cell lymphoma: treatment strategies and patterns of failure $<\sup />$. Leuk Lymphoma 2018; 59: 2896-2903.

19. Vitolo U, Seymour JF, Martelli M, Illerhaus G, Illidge T, Zucca E, Campo E, Ladetto M. Extranodal diffuse large B-cell lymphoma (DLBCL) and primary mediastinal B-cell lymphoma: ESMO Clinical Practice Guidelines for diagnosis, treatment and follow-up. Ann Oncol. 2016;27:v91-102.

20. Yahalom J, Illidge T, Specht L, Hoppe RT, Li YX, Tsang R, Wirth A. Modern radiation therapy for extranodal lymphomas: field and dose guidelines from the International Lymphoma Radiation Oncology Group. Int J Radiat Oncol Biol Phys. 2015;92:11-31.

21. Rosenthal A, Younes A. High grade B-cell lymphoma with rearrangements of MYC and BCL2 and/or BCL6: Double hit and triple hit lymphomas and double expressing lymphoma. Blood Rev. 2017;31:37-42.

22. Ma Q, Chang Y, Li L, Li X, Wang X, Wu J, Fu X, Sun Z, Yu H, Zhang X, Zhou Z, Nan F, Li Z, Liu X, Zhao Q, Li Y, Zhang L, Zhang M, Zhang L. Efficacy of dose-adjusted EPOCH plus rituximab/R-CHOP regimens and the prognosis analysis in patients with MYC, BCL2/BCL6 gene copy number gain lymphoma and double-hit lymphoma: results from a single institution retrospective clinical study. Cancer Manag Res. 2019;11:1363-72. 
23. Pejša V, Prka Ž, Lucijanić M, Mitrović Z, Piršić M, Jakšić O, Ajduković R, Kušec R. Rituximab with dose-adjusted EPOCH as first-line treatment in patients with highly aggressive diffuse large B-cell lymphoma and autologous stem cell transplantation in selected patients. Croat Med J. 2017:58:40-8

24. Dunleavy K, Fanale MA, Abramson JS, Noy A, Caimi PF, Pittaluga S, Parekh S, Lacasce A, Hayslip JW, Jagadeesh D, Nagpal S, Lechowicz MJ, Gaur R, Lucas A, Melani C, Roschewski M, Steinberg SM, Jaffe ES, Kahl B, Friedberg JW, Little RF, Bartlett NL, Wilson WH. Dose-adjusted EPOCH-R (etoposide, prednisone, vincristine, cyclophosphamide, doxorubicin, and rituximab) in untreated aggressive diffuse large B-cell lymphoma with MYC rearrangement: a prospective, multicentre, single-arm phase 2 study. Lancet Haematol. 2018;5:e609-17.

25. Purroy N, Bergua J, Gallur L, Prieto J, Lopez LA, Sancho JM, García-Marco JA, Castellví J, Montes-Moreno S, Batlle A, de Villambrosia SG, Carnicero F, Ferrando-Lamana L, Piris MA, Lopez A. Long-term follow-up of doseadjusted EPOCH plus rituximab (DA-EPOCH-R) in untreated patients with poor prognosis large B-cell lymphoma. A phase II study conducted by the Spanish PETHEMA Group. Br J Haematol. 2015;169:188-98.

26. Savage KJ, Slack GW, Mottok A, Sehn LH, Villa D, Kansara R, Kridel R, Steidl C, Ennishi D, Tan KL, Ben-Neriah S, Johnson NA, Connors JM, Farinha P, Scott DW, Gascoyne RD. Impact of dual expression of MYC and BCL2 by immunohistochemistry on the risk of CNS relapse in DLBCL. Blood. 2016;127:2182-8.

27. Savage KJ. Secondary CNS relapse in diffuse large B-cell lymphoma: defining high-risk patients and optimization of prophylaxis strategies. Hematology Am Soc Hematol Educ Program. 2017;2017:578-86.

28. Kansara R. Central nervous system prophylaxis strategies in diffuse large $B$ cell lymphoma. Curr Treat Options Oncol. 2018;19:52.

29. Gleeson M, Counsell N, Cunningham D, Chadwick N, Lawrie A, Hawkes EA, McMillan A, Ardeshna KM, Jack A, Smith P, Mouncey P, Pocock C, Radford JA, Davies J, Turner D, Kruger A, Johnson P, Gambell J, Linch $D$. Central nervous system relapse of diffuse large B-cell lymphoma in the rituximab era: results of the UK NCRI R-CHOP-14 versus 21 trial. Ann Oncol. 2017;28:2511-6.

30. Holte H, Leppä S, Björkholm M, Fluge O, Jyrkkiö S, Delabie J, Sundström C, Karjalainen-Lindsberg ML, Erlanson M, Kolstad A, Fosså A, Ostenstad B, Löfvenberg E, Nordström M, Janes R, Pedersen LM, Anderson H, Jerkeman M, Eriksson M. Dose-densified chemoimmunotherapy followed by systemic central nervous system prophylaxis for younger high-risk diffuse large B-cell/follicular grade 3 lymphoma patients: results of a phase II Nordic Lymphoma Group study. Ann Oncol. 2013;24:1385-92.

31. Hosein PJ, Maragulia JC, Salzberg MP, Press OW, Habermann TM, Vose JM, Bast M, Advani RH, Tibshirani R, Evens AM, Islam N, Leonard JP, Martin P, Zelenetz AD, Lossos IS. A multicentre study of primary breast diffuse large B-cell lymphoma in the rituximab era. Br J Haematol. 2014;165:358-63.

32. Siegal T, Goldschmidt N. CNS prophylaxis in diffuse large B-cell lymphoma: if, when, how and for whom? Blood Rev. 2012;26:97-106.

33. Kim YR, Kim SJ, Cheong JW, Yang DH, Lee H, Eom HS, Sung YO, Kim HJ, Kang HJ, Lee WS, Park Y, Yang WI, Min YH, Kim JS. The different roles of molecular classification according to upfront autologous stem cell transplantation in advanced-stage diffuse large B cell lymphoma patients with elevated serum lactate dehydrogenase. Ann Hematol. 2016;95:1491-501.

34. Herrera AF, Rodig SJ, Song JY, Kim Y, Griffin GK, Yang D, Nikolaenko L, Mei M, Bedell V, Dal Cin P, Pak C, Alyea EP, Budde LE, Chen R, Chen YB, Chan WC, Cutler CS, Ho VT, Koreth J, Krishnan A, Murata-Collins JL, Nikiforow S, Palmer J, Pihan GA, Pillai R, Popplewell L, Rosen ST, Siddiqi T, Sohani AR, Zain J, Kwak LW, Weisenburger DD, Weinstock DM, Soiffer RJ, Antin JH, Forman SJ, Nademanee AP, Armand P. Outcomes after allogeneic stem cell transplantation in patients with double-hit and double-expressor lymphoma. Biol Blood Marrow Transplant. 2018;24:514-20.

35. Xiao Z, Li J, Miao K. Allogeneic hematopoietic stem cell transplantation in relapsed/refractory diffuse large B cell lymphoma. Curr Stem Cell Res Ther. 2017;12:14-8

36. Wilson WH, Grossbard ML, Pittaluga S, Cole D, Pearson D, Drbohlav N, Steinberg SM, Little RF, Janik J, Gutierrez M, Raffeld M, Staudt L, Cheson BD, Longo DL, Harris N, Jaffe ES, Chabner BA, Wittes R, Balis F. Doseadjusted EPOCH chemotherapy for untreated large B-cell lymphomas: a pharmacodynamic approach with high efficacy. Blood. 2002;99:2685-93.

37. Hu K, Gao JJ, Li QH, Tian L, Wan W, Zhao W, Wang JJ, Fu L. Autologous hematopoietic stem cell transplantation as first-line consolidation therapy can improve the prognosis of diffuse large B-cell lymphoma with high expression of MYC protein. Kaohsiung J Med Sci. 2019;35:425-31.

38. Jiang S, Qin Y, Jiang H, Liu B, Shi J, Meng F, Liu P, Yang J, Yang S, He X, Zhou S, Gui L, Liu H, Lin J, Han-Zhang H, Shi Y. Molecular profiling of Chinese R-CHOP treated DLBCL patients: identifying a high-risk subgroup. Int J Cancer. 2020;147:2611-20.

39. Qin Y, Jiang S, Liu P, Yang J, Yang S, He X, Zhou S, Gui L, Lin J, Du X, Yi Y, Sun $Y$, Shi Y. Characteristics and management of TP53-mutated diffuse large B-cell lymphoma patients. Cancer Manag Res. 2020;12:11515-22.

40. Clipson A, Barrans S, Zeng N, Crouch S, Grigoropoulos NF, Liu H, Kocialkowski S, Wang M, Huang Y, Worrillow L, Goodlad J, Buxton J, Neat M, Fields P, Wilkins B, Grant JW, Wright P, Ei-Daly H, Follows GA, Roman E, Watkins AJ, Johnson PW, Jack A, Du MQ. The prognosis of MYC translocation positive diffuse large B-cell lymphoma depends on the second hit. J Pathol Clin Res. 2015;1:125-33.

41. Deng M, Xu-Monette ZY, Pham LV, Wang X, Tzankov A, Fang X, Zhu F, Visco C, Bhagat G, Dybkaer K, Chiu A, Tam W, Zu Y, Hsi ED, You H, Huh J, Ponzoni M, Ferreri AJM, Møller MB, Parsons BM, Hagemeister F, van Krieken JH, Piris MA, Winter JN, Li Y, Xu B, Liu P, Young KH. Aggressive B-cell lymphoma with MYC/TP53 dual alterations displays distinct clinicopathobiological features and response to novel targeted agents. Mol Cancer Res. 2021;19:249-60.

\section{Publisher's Note}

Springer Nature remains neutral with regard to jurisdictional claims in published maps and institutional affiliations.

\footnotetext{
Ready to submit your research? Choose BMC and benefit from:

- fast, convenient online submission

- thorough peer review by experienced researchers in your field

- rapid publication on acceptance

- support for research data, including large and complex data types

- gold Open Access which fosters wider collaboration and increased citations

- maximum visibility for your research: over $100 \mathrm{M}$ website views per year
}

At BMC, research is always in progress.

Learn more biomedcentral.com/submissions 